\title{
Isolation and Characterization of an Anaerobic, Cellulolytic Bacterium, Clostridium celerecrescens sp. nov.
}

\author{
M. LL. PALOP, S. VALLES, F. PIÑAGA, AND A. FLORS* \\ Unidad de Bioingeniería, Instituto de Agroquímica y Tecnología de Alimentos, Consejo Superior de \\ Investigaciones Científicas, 46010 Valencia, Spain
}

\begin{abstract}
A new anaerobic mesophilic cellulolytic clostridium isolated from a methanogenic cellulose-enriched culture is described. Optimal growth occurs at $35^{\circ} \mathrm{C}$ and $\mathrm{pH}$ 7.0. Fructose, maltose, rhamnose, lactose, glucose, xylose, ribose, mannose, raffinose, cellobiose, arabinose, galactose, mannitol, adonitol, esculin, salicin, and trehalose serve as substrates for growth. The major fermentation products from cellulose or cellobiose are ethanol, acetate, formate, butyrate, isobutyrate, isovalerate, caproate, lactate, succinate, $\mathrm{CO}_{2}$, and $\mathrm{H}_{2}$. The deoxyribonucleic acid base composition is $38 \mathrm{~mol} \%$ guanine plus cytosine. The type strain is 18A (= CECT 954).
\end{abstract}

The potential for converting cellulosic wastes into industrial substrates has stimulated current interest in cellulose fermentation. Among the methods proposed for this purpose, anaerobic digestion offers economic and pollution control advantages.

Many cellulolytic microorganisms have been isolated from the human colon (1), soil (18), estuarine sediments (13), freshwater sediments (9), decomposing vegetation $(10,17)$, and the bovine rumen $(4,5)$. In contrast, little attention has been paid to cellulolytic bacteria involved in artificially confined methanogenic systems. This work refers to the isolation and characterization of a distinct cellulolytic bacterium from a methanogenic digestor.

\section{MATERIALS AND METHODS}

Media. The basal medium was CM3 described by Weimer and Zeikus (24), except that $\mathrm{Na}_{2} \mathrm{~S}$ was omitted and the final cysteine hydrochloride concentration was $0.55 \mathrm{~g} /$ liter. The $\mathrm{pH}$ was adjusted to 7.2 with $1 \mathrm{M} \mathrm{NaOH}$. Basal medium, supplemented with $0.5 \%$ (wt/vol) Whatman CF-11 cellulose powder and $1.0 \%$ agar, was used for strain isolation. For detecting cellulolytic activities, the carbon source was a strip (6 by $1 \mathrm{~cm})$ of Whatman no. 1 filter paper. For culture maintenance, basal medium was supplemented with $0.5 \%$ (wt/vol) Whatman CF-11 cellulose powder under oxygenfree nitrogen. Soluble carbohydrates, used as the carbon source for biochemical tests, were autoclaved separately (30 min, $110^{\circ} \mathrm{C}$ ) and added to the sterile basal medium just before inoculation.

Anaerobic culture methods. Throughout this study, the anaerobic technique of Hungate (7) modified by Bryant (2) was followed. Standard test tubes $(16 \times 125 \mathrm{~mm}$; Bellco Glass, Inc.) sealed with butyl rubber stoppers and screw caps (Bellco Glass) were used as culture tubes. All cultures were incubated at $37^{\circ} \mathrm{C}$ without agitation.

Isolation procedures. A methanogenic culture, started with a cow manure inoculum, was the source of the new microorganism. Isolation was effected from a semicontinuous enrichment (hydraulic retention time, 105 days) obtained by weekly feeding for 1 year a suspension of Whatman CF-11 cellulose powder in the defined medium of Khan et al. (8). Serial dilutions in prereduced physiological saline were used to inoculate cellulose agar plates in an anaerobic chamber. The inoculated plates were incubated in GasPak anaerobic

\footnotetext{
* Corresponding author.
}

jars under $80 \% \mathrm{~N}_{2}-20 \% \mathrm{CO}_{2}$ at $37^{\circ} \mathrm{C}$. Colonies with clearing zones of cellulose digestion were picked and transferred into tubes containing CM3 medium supplemented with a strip of filter paper. The tubes were incubated until the filter paper showed signs of decay, and samples were replated on cellulose agar. The procedure was repeated several times to assure the purity of the culture by colony appearance and microscopic examination. To confirm the purity of the culture, brucella blood agar, prepared according to the Wadsworth manual (23), was used. The isolate used in this study was maintained by weekly transfers in liquid medium.

Morphology. Living and stained cells were examined by light microscopy. Flagella were examined by electron microscopy. For this last purpose, a colony grown on brucella blood agar plates was suspended in physiological saline; a drop of the suspension was placed on a Formvar-coated copper grid and stained with $1 \%$ (wt/vol) phosphotungstic acid solution. Observations were made with a Zeiss model EM-10C electron microscope.

Biochemical reactions. Biochemical tests were performed by the standard procedures described in the Anaerobe Laboratory Manual (6). Tests were read as soon as microorganisms showed good growth (optical density at $625 \mathrm{~nm}=$ 0.8 , equivalent to $0.88 \mathrm{mg}$ of dried cells per $\mathrm{ml}$ ) or one day after they achieved constant turbidity.

DNA base composition. The deoxyribonucleic acid (DNA) was isolated and purified by the method of Marmur (11) from cells grown for $24 \mathrm{~h}$ in basal medium with cellobiose $(6 \mathrm{~g} /$ liter) as the carbon source. Moles percent guanine plus cytosine $(\mathrm{G}+\mathrm{C})$ was estimated from the thermal denaturation temperature by the method of Marmur and Doty (12). $\mathrm{G}+\mathrm{C}$ content was calculated from the measured thermal denaturation temperature by the Owen and Hill (15) equation, $\%(\mathrm{G}+\mathrm{C})=50.9+2.08\left(T_{m}-T_{m}\right.$ ref $)$, with DNA from Escherichia coli as a reference.

Electrophoretic study of soluble proteins. Cells from 24-hold cultures in $5 \mathrm{ml}$ of brain heart infusion broth were harvested by centrifugation at $8,000 \times g$ for $10 \mathrm{~min}$, washed

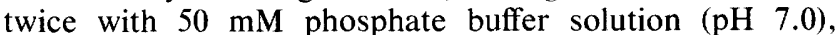
sedimented in conical tubes by centrifugation, and then suspended in $0.1 \mathrm{ml}$ of $0.062 \mathrm{M}$ tris(hydroxymethyl)aminomethane (Tris) chloride buffer ( $\mathrm{pH} \mathrm{6.8)}$. After $0.15 \mathrm{~g}$ of 250to $300-\mu \mathrm{m}$ diameter glass beads was added, tubes were placed in an ice bath and vortexed for two 2-min periods (3, $25)$. The cellular debris were removed by centrifugation at $15,000 \times g$ for $10 \mathrm{~min}$. After protein denaturation by heating $\left(100^{\circ} \mathrm{C}, 10 \mathrm{~min}\right)$ in the presence of excess sodium dodecyl 
TABLE 1. Differentiation of strain 18A from other mesophilic cellulolytic clostridia

\begin{tabular}{|c|c|c|c|c|c|c|}
\hline \multirow{2}{*}{ Characteristic } & \multicolumn{6}{|c|}{ Reaction $^{a}$} \\
\hline & C. cellobioparum & C. papyrosolvens & C. cellulolyticum & C. cellulovorans & C. populeti & Strain $18 \mathrm{~A}$ \\
\hline \multicolumn{7}{|l|}{ Growth on: } \\
\hline Adonitol & ND & - & - & ND & ND & + \\
\hline Dulcitol & + & - & - & ND & ND & - \\
\hline Gelatin & ND & - & - & - & + & + \\
\hline Glycerol & W & + & - & - & - & - \\
\hline Maltose & + & - & - & + & + & + \\
\hline Mannitol & - & - & - & ND & ND & + \\
\hline Mannose & + & - & W & + & - & + \\
\hline Raffinose & - & - & - & ND & ND & + \\
\hline Rhamnose & - & - & - & - & - & + \\
\hline Salicin & W & - & - & ND & ND & + \\
\hline Trehalose & - & - & - & - & - & + \\
\hline Indole production & - & - & - & ND & ND & + \\
\hline Milk test & - & - & - & ND & ND & + \\
\hline$\%(\mathrm{G}+\mathrm{C})$ & $25-28$ & 30 & 41 & $25-27$ & 28 & 38 \\
\hline
\end{tabular}

$a+$, Positive; - , negative; $W$, weak; ND, not determined.

sulfate and mercaptoethanol, samples were analyzed by electrophoresis in polyacrylamide slab gels by using $4 \%$ (stacking gel) and $12 \%$ (separating gel) acrylamide (21). Electrophoresis was run at $10^{\circ} \mathrm{C}$ at an increasing voltage from 80 to $130 \mathrm{~V}$ and at about $25 \mathrm{~mA}$ initial current.

Temperature and pH studies. The temperature and $\mathrm{pH}$ effects on the growth rate of the organism were determined in cellobiose broth. Three tubes were inoculated and incubated for each temperature and $\mathrm{pH}$. Growth was measured as optical density at $625 \mathrm{~nm}$ on a Bausch \& Lomb Spectronic 20 spectrophotometer, and the average value was calculated.

Fermentation end-product analysis. Volatile fatty acids, alcohols, and nonvolatile acids were determined in fermentation broth samples $(2.5 \mathrm{ml})$ after deproteinizing with $0.1 \mathrm{ml}$ of $\mathrm{ZnCl}_{2}(10 \% \mathrm{wt} / \mathrm{vol})$ and centrifuging at $12,000 \times \mathrm{g}$ for 15 min. The preparation of ether extracts and the chromatographic analysis of the extracted components were carried out by the methods of Holdeman et al. (6).

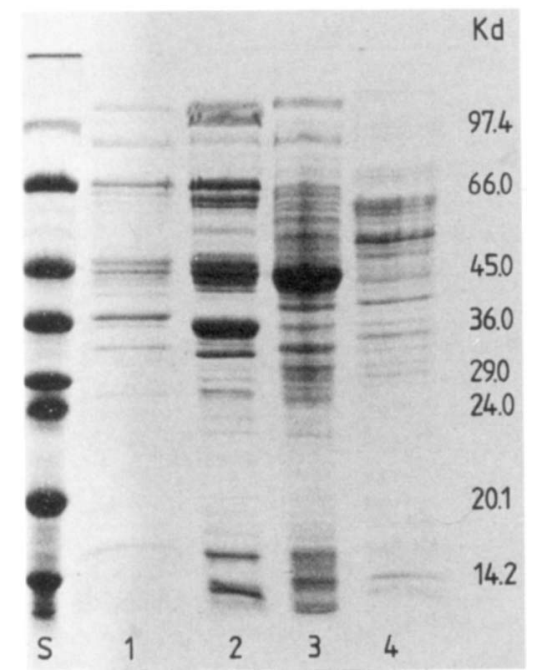

FIG. 1. Sodium dodecyl sulfate-polyacrylamide gel electrophoresis of cellular proteins of some cellulolytic clostridia. Lanes: $1, C$. papyrosolvens; 2 , C. cellulolyticum; 3 , strain $18 \mathrm{~A} ; 4, C$. cellulovorans. The numbers on the right refer to the molecular weights of the standards in track S.
Headspace gases were analyzed by gas chromatography at $50^{\circ} \mathrm{C}$ on Chromosorb 102 (80 to $100 \mathrm{mesh}$ ) in a $2-\mathrm{m}$-long by 2 -mm-inside-diameter column. The effluent from the column was fed into a molecular sieve $0.5-\mathrm{nm}$ column ( $2-\mathrm{m}$ long by 2-mm inside-diameter) at room temperature. Argon was used as the carrier gas with a flow rate of $27 \mathrm{ml} / \mathrm{min}$. Effluent gases were detected by thermal conductivity.

\section{RESULTS AND DISCUSSION}

The enrichment and isolation procedures yielded four anaerobic cellulolytic isolates from which strain $18 \mathrm{~A}$ was selected for identification on the basis of its cellulolytic capacity for filter paper degradation.

Preliminary tests showed that the isolate was a rodshaped, gram-positive, obligately anaerobic sporeforming bacterium. The DNA base composition was $38 \mathrm{~mol} \% \mathrm{G}+\mathrm{C}$.

On the basis of the identification scheme of the last edition of Bergey's Manual of Systematic Bacteriology (22), the isolate was identified as a member of the genus Clostridium. According to this manual, the only mesophilic members of the genus Clostridium recognized as cellulolytic are $C$. cellobioparum and $C$. papyrosolvens.

Isolate 18A differs from $C$. cellobioparum and C. papyro-

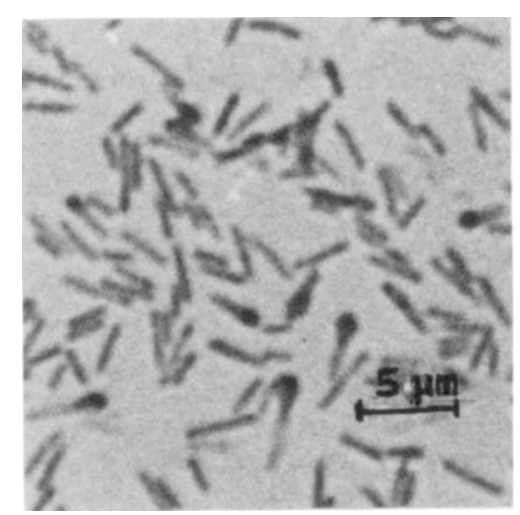

FIG. 2. Forty-eight-hour-old cells grown on brucella blood agar. 


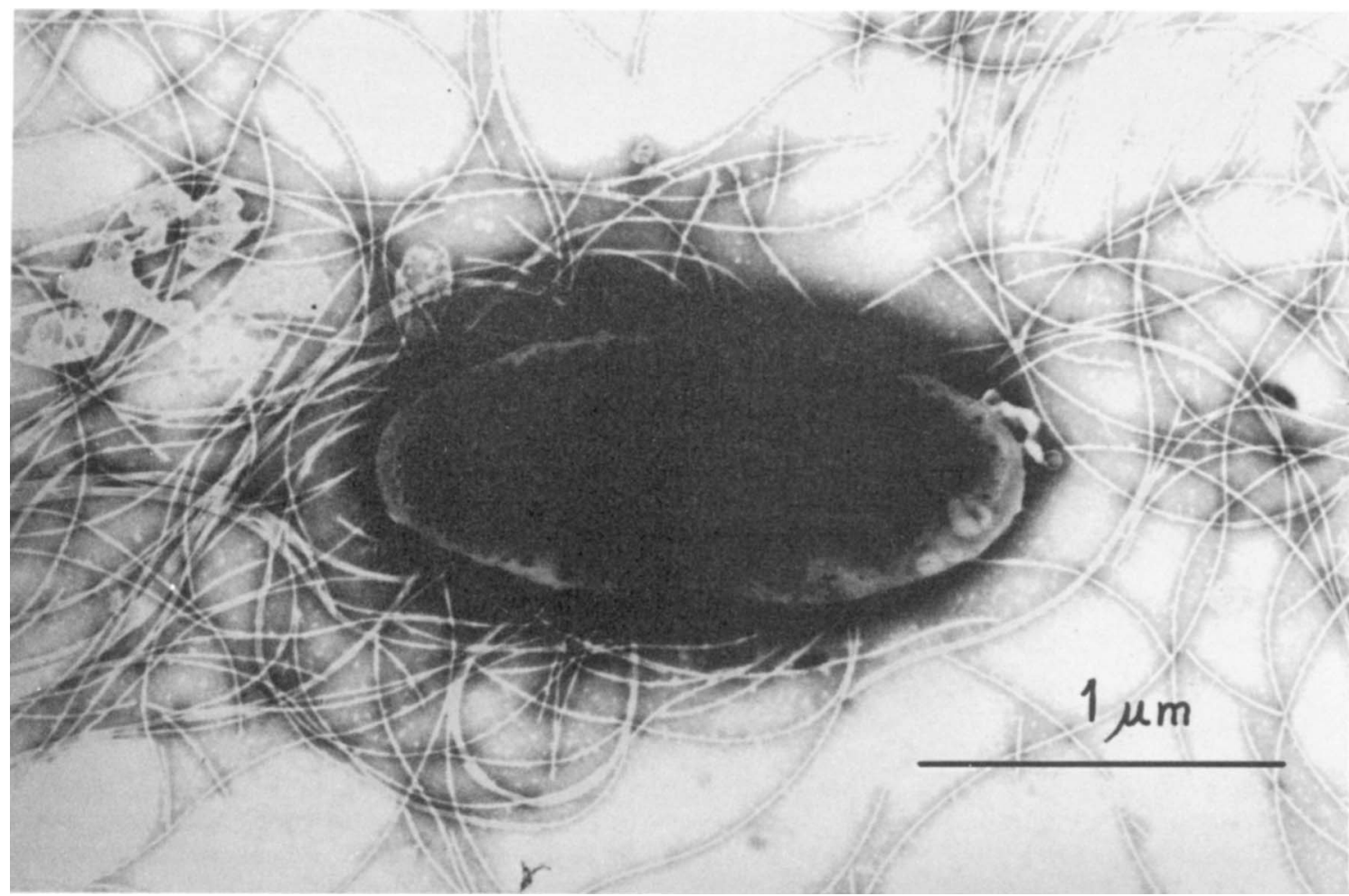

FIG. 3. Electron micrograph of $C$. celerecrescens.

solvens (Table 1) by fermenting mannitol, raffinose, rhamnose, and trehalose, and in that it is positive for indole production and for milk tests (digestion with clot formation). The $\mathrm{G}+\mathrm{C}$ contents of $C$. cellobioparum and $C$. papyrosolvens are 28 and $30 \mathrm{~mol} \%$, respectively.

Other mesophilic cellulolytic clostridia include $C$. cellulolyticum (17), C. cellulovorans (19), and C. populeti (20). The biochemical characteristics of these species (Table 1) also differ from those of our isolate. The protein electrophoretic pattern of isolate $18 \mathrm{~A}$ can clearly be distinguished from those of $C$. papyrosolvens, $C$. cellulolyticum, and $C$. cellulovorans (Fig. 1). In addition, isolate 18A differs from $C$. cellobioparum, $C$. papyrosolvens, and $C$. cellulolyticum by producing butyrate as a major metabolic product.

Another distinguishing characteristic of isolate $18 \mathrm{~A}$ is its high specific growth rate, $0.564 \mathrm{~h}^{-1}$, attained at a cellobiose concentration of $6 \mathrm{~g} /$ liter. Table 2 compares this value with those published for other cellulolytic microorganisms.

We therefore propose the establishment of a new species, Clostridium celerecrescens sp. nov. (ce'le. re. cres. cens. L.

TABLE 2. Specific growth rate of some cellulolytic microorganisms at optimal conditions of culture

\begin{tabular}{lccccc}
\hline \multicolumn{1}{c}{ Microorganism } & $\begin{array}{c}\text { Temp } \\
\left({ }^{\circ} \mathrm{C}\right)\end{array}$ & $\mathrm{pH}$ & $\begin{array}{c}\text { Concn of } \\
\text { cellobiose } \\
(\mathrm{g} / \text { /liter })\end{array}$ & $\begin{array}{c}\mu \\
\left(\mathrm{h}^{-1}\right)\end{array}$ & $\begin{array}{c}\text { Refer- } \\
\text { ence }\end{array}$ \\
\hline Acetivibrio cellulolyticus & 35 & 7.0 & 10.0 & 0.170 & 16 \\
Clostridium cellulolyticum & 35 & 7.0 & 10.0 & 0.099 & 17 \\
Clostridium papyrosolvens & 37 & 7.0 & 6.0 & 0.266 & $-{ }^{a}$ \\
Clostridium thermocellum $\mathrm{H} 1$ & 60 & 7.0 & 6.8 & 0.330 & 14 \\
Strain 18A & 35 & 7.0 & 6.0 & 0.564 & \\
\hline
\end{tabular}

\footnotetext{
"Unpublished results obtained in this laboratory.
}

adv. celere, fast; crescens, L. pres. part. of verb crescere, to grow; M.L. adj. celerecrescens, intended to reflect the fast growth of the organism).

Cells are straight to slightly curved rods, 2- to $4-\mu \mathrm{m}$ long by 0.5 - to $0.8-\mu \mathrm{m}$ wide. Vegetative cells stain gram positive, although they decolorize readily in older cultures. Endospores are spherical and terminal and produce swollen cells (Fig. 2). Cells are motile by means of peritrichous flagella (Fig. 3).

On cellulose agar medium, colonies appear after 10 to 14 days of incubation at $37^{\circ} \mathrm{C}$ and exhibit halos of cellulolysis. Deep colonies are smooth, circular, approximately $0.5 \mathrm{~mm}$ in diameter, translucent, and unpigmented.

C. celerecrescens ferments cellulose, cellobiose, glucose, fructose, galactose, mannitol, maltose, adonitol, rhamnose,

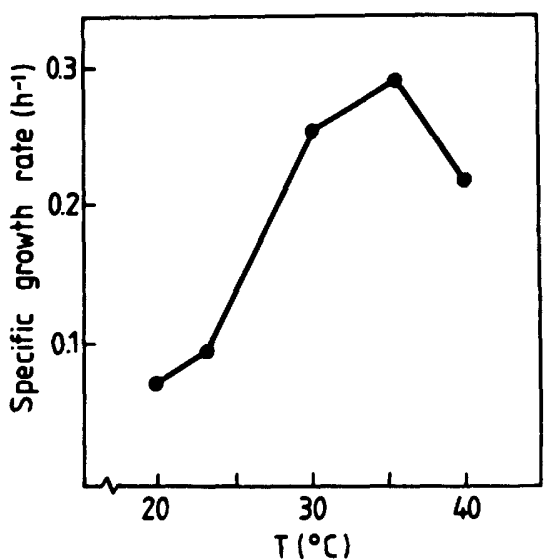

FIG. 4. Effect of temperature on growth of $C$. celerecrescens. 


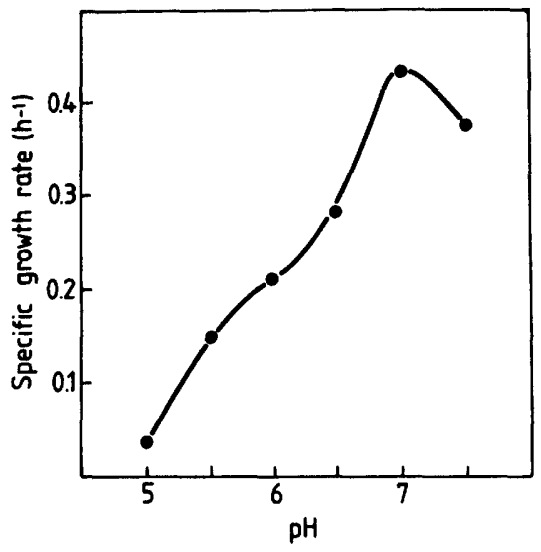

FIG. 5. Effect of $\mathrm{pH}$ on growth of C. celerecrescens.

xylose, ribose, mannose, raffinose, trehalose, arabinose, and esculin. It weakly ferments lactose, melezitose, melibiose, sorbose, and sucrose. It does not ferment dulcitol, erythritol, glycerol, inulin, sorbitol, and starch.

Fermentation products in cellobiose and cellulose broth are ethanol, acetate, formate, butyrate, isobutyrate, isovalerate, caproate, lactate, succinate, $\mathrm{H}_{2}$, and $\mathrm{CO}_{2}$.

Gelatin is liquefied and indole is produced. Catalase, lipase, lecithinase, and urease are negative. Nitrate reduction and casein hydrolysis are negative. Acetyl methyl carbinol is not produced. Milk digestion and curd formation are positive.

Optimum growth temperature is between 30 to $37^{\circ} \mathrm{C}$. Growth rate decreases substantially at $23^{\circ} \mathrm{C}$ (Fig. 4).

Optimum $\mathrm{pH}$ is near 7.0. Growth rate decreases substantially under $\mathrm{pH} 7$ and over $\mathrm{pH} 8$ (Fig. 5).

The DNA base composition is $38 \mathrm{~mol} \% \mathrm{G}+\mathrm{C}$.

The source was a methanogenic culture started with a cow manure inoculum.

The type strain is 18A (= CECT 954) (Colección Española de Cultivos Tipo).

\section{ACKNOWLEDGMENTS}

This research was supported by a grant from the Comision Asesora de Investigación Científica y Técnica.

We thank J. Buesa (University of Valencia) for his assistance in taking the electron micrograph, A. Ventosa (University of Sevilla) for his collaboration in $\mathrm{G}+\mathrm{C}$ content determination, and $\mathrm{M}$. A. Argomaniz for her excellent technical assistance.

\section{LITERATURE CITED}

1. Betaine, H. G., B. A. Linehan, M. P. Bryant, and L. V. Holdeman. 1977. Isolation of a cellulolytic Bacteroides sp. from human feces. Appl. Environ. Microbiol. 33:1009-1010.

2. Bryant, M. P. 1972. Commentary on the Hungate technique for culture of anaerobic bacteria. Ann. J. Clin. Nutr. 25:1324-1328.

3. Cato, E. P., E. D. Hash, L. V. Holdeman, and W. E. C. Moore. 1982. Electrophoretic study of Clostridium species. J. Clin. Microbiol. 15:688-702.

4. Hobson, P. N., and R. J. Wallace. 1982. Microbial ecology and activities in the rumen. I. Crit. Rev. Microbiol. 9:162-225.

5. Hobson, P. N., and R. J. Wallace. 1982. Microbial ecology and activities in the rumen. II. Crit. Rev. Microbiol. 9:253-320.
6. Holdeman, L. V., E. P. Cato, and W. E. C. Moore (ed.). 1977. Anaerobe laboratory manual, 4th ed. Virginia Polytechnic Institute and State University, Blacksburg.

7. Hungate, R. E. 1969. A roll tube method for cultivation of strict anaerobes, p. 117-132. In J. R. Norris and D. W. Ribbons (ed.), Methods in microbiology, 3B. Academic Press, Inc. (London), Ltd., London.

8. Khan, A. W., T. M. Trottier, G. B. Patel, and S. M. Martin. 1979. Nutrient requirement for the degradation of cellulose to methane by a mixed population of anaerobes. J. Gen. Microbiol. 112:365-372.

9. Leschine, S. B., and E. Canale-Parola. 1983. Mesophilic cellulolytic clostridia from freshwater environments. Appl. Environ. Microbiol. 46:728-737.

10. Madden, R. H. 1983. Isolation and characterization of Clostridium stercorarium sp. nov., a cellulolytic thermophile. Int. J. Syst. Bacteriol. 33:837-840.

11. Marmur, J. 1961. A procedure for the isolation of deoxyribonucleic acid from microorganisms. J. Mol. Biol. 3:208-218.

12. Marmur, J., and P. Doty. 1962. Determination of the base composition of deoxyribonucleic acid from its thermal denaturation point. J. Mol. Biol. 5:109-118.

13. Massen, R. H., M. J. Bryder, and N. J. Poole. 1982. Isolation and characterization of an anaerobic cellulolytic bacteria, Clostridium papyrosolvens $\mathrm{sp}$. nov. Int. J. Syst. Bacteriol. 32:87-91.

14. Ng, T. K., P. J. Weimer, and J. G. Zeikus. 1977. Cellulolytic and physiological properties of Clostridium thermocellum. Arch. Microbiol. 114:1-7.

15. Owen, R. J., and L. R. Hill. 1979. The estimation of base composition, base pairing and genome sizes of bacterial DNAs, p. 277-292. In F. A. Skinner and D. W. Lovelock (ed.), Identification methods for microbiologists, 2nd ed. Academic Press, Inc. (London), Ltd., London.

16. Patel, G. B., and C. R. Mackenzie. 1982. Metabolism of Acetivibrio cellulolyticus during optimized growth on glucose, cellobiose and cellulose. Eur. J. Appl. Microbiol. Technol. 16:212218.

17. Petitdemange, E., F. Caillet, J. Giallo, and C. Gaudin. 1984. Clostridium cellulolyticum sp. nov., a cellulolytic mesophilic species from decayed grass. Int. J. Syst. Bacteriol. 34:155-159.

18. Skinner, F. A. 1960 . The isolation of an anaerobic cellulosedecomposing bacterium from soil. J. Gen. Microbiol. 22:539 554.

19. Sleat, R., R. A. Mah, and R. Robinson. 1984. Isolation and characterization of an anaerobic, cellulolytic bacterium, Clostridium cellulovorans sp. nov. Appl. Environ. Microbiol. 48:8893.

20. Sleat, R., and R. A. Mah. 1985. Clostridium populeti sp. nov., a cellulolytic species from a woody-biomass digestor. Int. J. Syst. Bacteriol. 35:160-163.

21. Smith, B. J. 1984. SDS polyacrylamide electrophoresis of proteins, p. 41-55. In J. M. Walker (ed.), Methods in molecular biology, vol. 1. Proteins. Humana Press. Clifton, N.J.

22. Sneath, P. H. A., M. S. Mair, M. E. Sharpe, and J. G. Holt. 1986. Bergey's manual of systematic bacteriology, vol. 2, 1st ed. The Williams \& Wilkins Co., Baltimore.

23. Sutter, V. L., M. A. C. Citron, M. Edelstein, and S. Finegold. 1985. Wadsworth anaerobic bacteriology manual, 4th ed. Star Publishing Co., Belmont, Calif.

24. Weimer, P. J., and J. G. Zeikus. 1977. Fermentation on cellulose and cellobiose by Clostridium thermocellum in the absence and presence of Methanobacterium thermoautotrophicum. Appl. Environ. Microbiol. 33:289-297.

25. Wexler, H., H. E. Mulligan, and S. M. Finegold. 1984. Polyacrylamide gel electrophoresis patterns produced by Clostridium difficile. Rev. Infect. Dis. 6(Suppl. 1):5229-5234. 